\title{
ZISWAF ROLE IN THE FORMATION OF JUSTICE OF THE MUSLIM REDISTRIBUTIVE
}

\author{
Nurlailiyah Aidatus Sholihah \\ Sekolah Tinggi Agama Islam Darussalam Subang \\ E-mail: nurlailiyahidatussholihah@staidarussalam.ac.id \\ Fikry Ramadhan Suhendar \\ Sekolah Tinggi Ilmu Ekonomi Miftahul Huda Subang \\ Email: fikry@stiemifdasubang.ac.id
}

\begin{abstract}
Ownership in Islam is essentially belongs to God and man is merely a surrogate recipient of Him. Everything that God entrusted to man should be put to good use in order to create a justice that is the core of Maqasid ash-Shari'ah. To create the justice, Islam requires that every Muslim who is able to issue a charity. With the obligation to pay zakat is expected to reduce the inequities that exist in society. In the economic field, the Muslim economists have different models related to the role of zakat to achieve justice. This article aims to explain some of the models as expressed by Chapra, Choudury and other economists. The method used in this paper is a descriptive analytical method, where the authors will describe the models offered by economists for analysis to obtain the proper model as a solution if it can be applied in Indonesia. Data obtained by the literature search, which the authors seek the literature relating to the charity as well as the opinions of economists in overcoming injustice in society. According to Chapra there are four aspects to realize maqashid mutually reinforcing and can give effect to the allocation and distribution of existing resources. in which authors seek the literature relating to the charity as well as the opinions of economists in overcoming injustice in society. According to Chapra there are four aspects to realize maqashid mutually reinforcing and can give effect to the allocation and distribution of existing resources. in which authors seek the literature relating to the charity as well as the opinions of economists in overcoming injustice in society. According to Chapra there are four aspects to realize maqashid mutually reinforcing and can give effect to the allocation and distribution of existing resources.
\end{abstract}

Keywords: Justice, charity, ash-Shariah maqashid

\section{A. INTRODUCTION}

Basically God has determined rizki on everyone with different levels based on the results of each business as defined in Surat al-Nahl: 71. The differences will become the foundation the necessity to share for others so that God requires that rich people to give the right -hak the poor and needy namely by removing zakat as in Surah Al-dzariyat: 19 (Al-Zuhaili, 2008, pp. 643-645), This proves that the disparity in income is not a necessity but something to be removed by means of redistribution of wealth as defined in Islam as through charity, donation, Sadaqah and endowments(Rahim, 2015, p. 28),

Zakat according to the language is growing and growing. Zakat can also be interpreted sacred, praise and clean of debris. Some of these meanings can be seen as in Surah At-Tauba: 103 show that people who fulfill zakat shadaqah in this case means he has to purify himself of sin, with the charity she has extended its reward and treasure(Al-Zuhaili, 2008, p. 642), Zakat according to Law Compilation of Islamic Economics and Management Act of Zakat is a treasure that must be set aside by a Muslim or institution that is owned by the Muslims under the provisions of the religion to then be given to those who deserve it(Association of Legislation, 2010, pp. 162, 196), 
Terminology Zakat in the Quran has several terms, such as infaq as in Surah Al-Tawbah: 34 which shows that charity is a treasure handover that aims to do good in the way of Allah. Zakat is also referred to as Sadaqah as in Surah Al-Tawbah: 60 indicating that execution as a form of charity is someone closer to Allah. In addition, al-Quran also uses the term haq as in Surah Al-dzariyat: 19, this shows that the inside of one's possessions are the rights of others should be given so that people who are entitled to receive zakat called by mustahiq(Sari, 2006, p. 3), Some of the meanings of zakat above shows that all the works that aims to get closer to God can be referred to as sadaqah in the form of material and non-material, while the term infaq more shows on providing both material. Thus, the term charity show on granting compulsory while Sadaqah and infaq can show the administration that is sunnah or voluntary.

Based on the above background, the focus of study in this discussion is how the models offered by economists that charity as an obligation for Muslims to give redistributive justice so as to eradicate poverty in Muslim countries, especially in Indonesia.

\section{B. METHODS}

The method used in this research is descriptive analytic(Dillah, 2015, p. 145) qualitative (Moleong, 2007, p. 157), Researchers will analyze the models offered by economists about the role of charity towards redistributive justice in Muslim countries for which data are qualitative. Presentation of results of the analysis in the form of descriptive narrative of the inductive method, so that the authors can conclude that the method can be applied in Indonesia to reduce poverty.

\section{RESULT AND DISCUSSION}

\section{Zakat provision}

The obligation to pay zakat, there are a few verses of al-Quran mentioned obligations after liability for prayed among which Surat al-Baqara: 43, Surat al-Tawbah: 103, Surat al-An'am: 141 and several other verses. In Surat al-Tawbah: 103 editors used is the command to take tithes that must be removed, if the clause is implemented in the legislation, the obligation to pay zakat can be done by force even for people who do not pay zakat can be given sanction by the government, as has been done by Abu Bakr who punishes those who do not pay zakat through killing him(Al-Zuhaili, 2008, pp. 646-647), Besides punishment in the world God has prepared punishment in the Hereafter as defined in Surat al-Tawbah: 34-35.

Behind the obligation to pay zakat of which there are several lessons to keep the treasure, to help poor people and that takes the form of zakat productive and consumptive, purify ourselves from nature griping and penurious as well as a form of gratitude for assets acquired(Al-Zuhaili, 2008, pp. 643-645),

Appropriation zakat has the provision that has been determined as the al-Quran which is divided into eight ashnaf as in Surah Al-Tawbah: 60 that is indigent, poor, amyl, converts, slaves, those in debt, and Ibn sabil sabilillah.

Mustahik fifth zakat is intended for people who are in debt with debt allowed by reason of Personality. In addition, zakat funds can also be allocated to companies in need of funding, and can also be used by the state as an alternative to debt financing. The funds are intended for the country, including the concept of emergency funds to avoid debt financing as well as to meet government requirements such as for the release of goods and services. If the charity fund will be used as an emergency fund of this type, borrowing by the government will be internal. Therefore, an increase in borrowing by the 
government from this fund will not increase inflation. This is in contrast with the financing of the budget deficit with foreign loans that could cause inflation to rise. If inflation occurs,(Choudury, 1986, p. 56),

\section{Problems Zakat}

As a Muslim-majority country in the world, Indonesia has a large zakat potential. Based on research data from Indonesia in 2016 Baznas zakat potential to reach Rp 286 trillion ( "Baznas: Potential of Zakat in Indonesia's Very Large | Republika Online," nd). However, zakat collected in 2016 amounted to 3,738,216,792,496 (National Zakat Statistics 2016, 2017, p. 5). This shows that there is as yet zakat potential optimally absorbed. There are several factors behind them is the first thing, the paradigm of society in view of the obligation of zakat just as personal piety. Secondly, there is a debate among fuqoha concerning the calculation, determination, until the allocation of the distribution of zakat. Third, the lack of government policies related to the collection of zakat. Four, systems and related mechanisms and the management of the distribution are not going well. Therefore, the potential zakat only be used for purely consumptive needs ( "ZAKAT AS AN INSTRUMENT IN FISCAL POLICY | Priyono | Al-mashlahah: Journal of Islamic Law and Islamic Social Institution," tt, p. 129).

The obligation to pay zakat, there are a few verses of al-Quran mentioned obligations after liability for prayed among which Surat al-Baqara: 43, Surat al-Tawbah: 103, Surat al-An'am: 141 and several other verses. In Surat al-Tawbah: 103 editors used is the command to take tithes that must be removed, if the clause is implemented in the legislation, the obligation to pay zakat can be done by force even for people who do not pay zakat can be given sanction by the government, as has been done by Abu Bakr who punishes those who do not pay zakat through killing him(Al-Zuhaili, 2008, pp. 646-647),

Grouping ashnaf above can be divided into two categories: first, ashnaf groups of one, three, five, and six can be used for training that can be employed as well as for the welfare of the family. Second, ashnaf category groups one, three, and five can be used for the rehabilitation of the elderly, venture capital for the unemployed, and so on(Choudury, 1986, p. 57),

The use of zakat funds that are intended for multiple categories on ashnaf can be expanded related things that support the needs mustahik, such as for training for the unemployed, to support the family welfare, rehabilitation of the elderly, venture capital productive for the unemployed, aid in case economic loss, education, social security and other costs for the needy (Choudury, 1986, p. 58),

\section{Role of Zakat By The Experts}

\section{a. Umer Chapra}

Chapra provide four aspects of strategy through the filter mechanism, the right motivation, the restructuring of the socio-economic and financial as well as the role of the state. If the fourth aspect can be run properly and mutually reinforcing, it can help the realization of Maqasid ash-Sharia and create a fair distribution of resources(Chapra, 2000, pp. 216), First, a filter mechanism possessed by Islam has a uniqueness that makes the moral aspect as a filter. Moral aspects into the filter in the filter of resources in accordance with the Islamic values to human welfare. Thus, the resources that do not have a benefit for wealth creation will be eliminated. The moral aspect also relates to restrictions that are owned by the human desire(Chapra, 2000, pp. 218),

Second, the right motivation is needed to achieve justice in the distribution of wealth. This is because a filter mechanism alone will not be enough to ensure equitable. Islam recognize the power of God is Aware of everything and life after death. God gives the threat of a painful punishment for anyone who does not believe in the Hereafter as defined in Surah Al-Isra: 10 Someone who truly believe that there is life after death he would think of the situation both in the world and in the hereafter. He would pay 
attention to their interests in the long-term implications for the life in the hereafter. Thus, he will seek to ensure kemashlahatan others with the desire not only concerned himself only. As in the case of consumption, by not showing mubadzir attitude and excessive even though financially he is able to do so. It can promote distributive justice by helping the poor meet their basic needs(Chapra, 2000, pp. 222),

Third,socio-economic restructuring and financially. Socio-economic and political conducive needed to support the implementation of the mechanism and motives correct filter. Social environment which is conducive not make showy attitude and material possessions as an achievement. In addition, the economic environment must also be repaired and arranged such that they do not deliver economic man the man who thought only of themselves and ignore the interests and welfare of others. If the system formed community environment capable of destroying even eliminate poor performance as described above as well as the existing economic conditions do not form the economic man distributive justice in the economic sphere and can be realized well maqashidnya(Chapra, 2000, pp. 225),

implementation of the concept and system of zakat can also reduce unemployment in the economy via three mechanisms, namely the implementation of zakat especially zakat productive that need workers, their change of category mustahik who did not have access to the economy into a group that is better economically, which then can increase the rate of participation labor, as well as the multiplier effect that can add jobs. According to Chapra as in Priyono stated that zakat is a social independence step taken with the full support of religion to help the poor people who can not meet their own basic needs. In addition, the charity must also provide a beneficial effect for the state, for example as a source of investment. Zakat redistribution of all the wealth would encourage tax payers to seek income from their property in order to pay zakat without reducing the treasure. In Islam, forbidden treasure hoarding, thereby helping increase investment later donated prosperity( "ZAKAT AS AN INSTRUMENT IN FISCAL POLICY | Priyono | Al-mashlahah: Journal of Islamic Law and Islamic Social Institution," tt, p. 128),

Fourth,role of the state has an important position to realize the restructuring as above. However, in Islam the state's role as the government does not intervene in the capitalist system, nor curb individual freedoms in the attempt, as in the socialist system nor substantiate the claim to resources that can lead to imbalances in the macroeconomic sphere as in the welfare state. In Islam, the state has an important role in order to bring prosperity to all people in a way to guarantee the balance of the individual ownership and social ownership, keeping the wheels of the economy to stay on the right path and prevent abuses committed by a group of people who have kepentigan. Therefore,(Chapra, 2000, pp. 227),

\section{b. Monzer Kahf}

According to Kahf sebagaiamana in Priyono confirms that the charity has a positive influence on the level of savings and investment. An increase of the savings as a result of an increase in revenue that can then lead to increased levels of investment. This is because there are provisions that savings have reached the limit will be charged a minimum or nishab zakat. Thus, the owners of the savings that have reached nishab aims to preserve the value of wealth so that they will choose the path of investment as a way out that will be selected by muzakki. Therefore, it can improve the overall investment figure. Investment is an important part in the economic development of a nation. Besides that, according Kahf as in Priyono also revealed that the charity can reduce the risk of financing or bad credit are commonly referred to as non-performing financing / NPF, this is because one of the charity fund allocation is for gharimin group that helps people who are deeply in debt. So in real terms, zakat will hit the 
unemployment rate and financing risk( "ZAKAT AS AN INSTRUMENT IN FISCAL POLICY | Priyono | Al-mashlahah: Journal of Islamic Law and Islamic Social Institution," tt, p. 127),

\section{c. Fahim Khan}

According to Khan, the charity has an important role to growth and employment. This can be seen when there is the possibility of saving decreased in the short term due to the Islamization of the economy such as the implementation of the instrument of charity in the community, then in a short time would be otherwise the instrument zakat will boost growth and savings in the long term so that can outperform conventional economics. In addition, the distribution of income zakat can also provide a positive effect on improvement of economic conditions. This can be done by giving them the opportunity to do productive things. Such Zakat is known as zakat productive.(Khan, 1995, p. 9),

\section{d. Choudury}

Zakat according to choudury is payment mandatory for the rich to those who are economically disadvantaged. This does not mean that the charity or charitable donations are voluntary, but charity is the main income of the Islamic state to spend on a group of people who have been determined as the al-Quran. Therefore charity is an obligation for all Muslims who have the ability to accomplish it(Choudury, 1986, p. 51),

Zakat has a function as a powerful tool of income distribution in the economic system of Islam. Thus, the state must intervene in case of intervention obligatory zakat implementation to change the economic position of a group of people who are poor, because of the absence of government intervention in the distribution of justice will not be achieved by itself(Choudury, 1986, p. 53-54),

The existence of a fair distribution of income can affect consumer demand patterns and the pattern of resource supply, which then in turn can determine the pattern of production. Patterns of production along with the consumption patterns to maximize the social welfare function(Choudury, 1986, p. 54),

Related efficient allocation of zakat shows that zakat can be attributed to income for the multiplier effect. It's can be seen through the relationship between the rate of zakat and income levels through changes in the level of investment. Occurrences revenue due to the multiplier effect pembenanan zakat imposed only on unproductive assets which the asset should be used productively. The situation will motivate the investors to utilize its capital so that it can increase investment. The increased investment will lead to increased revenues through the multiplier effect. Therefore, the presence of zakat can cause unproductive capital owners would use it for investment. The investment flow increased revenue made through the multiplier effect. Thus the presence of a positive multiplier effect is a function of zakat(Choudury, 1986, p. 55),

Based on some of the model introduced by the experts as the above, it can be seen that the charity has an important role in increasing investment. This is a logical consequence that muzakki not want any damages to property that should dizakatinya. This prompted muzakki to invest its assets so that his property is not diminished because it was issued to give charity. The allocation of the investments can help create jobs for the investment made into productive assets. The investments were also implicated in the emergence of a multiplier effect. Thus, the existence of Zakat funds are distributed fairly to achieve justice for the community.

According Anshory, economic growth will be followed by poverty reduction when poor people can increase their income. This shows that the change in income of the poor contributed to the rise in 
average income. However, economic growth does not necessarily reduce poverty if the increase in revenue just turning on the rich only. Therefore, economic growth can increase poverty if rich group revenue increase coupled with a decrease in income of the poor(Anshori, 2018, p. 7),

The role of charity, as stated by the experts showed that the charity has its own peculiarities which can not be found in the derma like any religion other than Islam. Characteristic of the zakat is an obligation that is material that has been defined by religion to transfer a portion of income and wealth from the rich to the poor, while the role of charity is similar to the charity in other religions are basically intended for the function of the purposes of religion, to the cost of living pastor or for the construction and maintenance of places of worship(lqbal, 1986, p. 180),

\section{CONCLUSION}

Zakat has an important role in the redistribution of justice related to Muslim countries. This is because the main objective of zakat is poor and needy groups. Based on some of the models presented by the experts can be seen that the right target allocation charity that can help drive economic growth, this is due to the presence of zakat can increase the income of the poor. Furthermore, zakat can also give birth to a multiplier effect that can then drive the wheels of business in society.

However, the implementation of good zakat zakat collection, management and distribution in Indonesia has not been able to run optimally caused by several factors, including the absence of legislation requiring the Muslim community to pay zakat to the institutions that have been ordered by the state. It requires governments to provide firmness through regulations that can support the implementation of zakat with makzimal so the role of zakat can be realized well.

\section{References}

Al-Zuhaili, W. (2008). Al-Fiqh al-Islami wa Adillatuhu (Vol. 2). Damascus: Dār Al-Fikr.

Anshori, A. (2018). Justice for Growth. Bandung: ubuntu PRESS.

Chapra, U. (2000). Islam and Economic Challenges (I. Abidin B., trans.). Jakarta: Gema Insani Press. Choudury, MA (1986). Contribution to Islamic Economic Theory "A Study in Social Economics." New York: St. Martin's Press.

Dillah, S. and P. (2015). Legal Research Methods. Bandung: Alfabeta.

Association of Legislation, (2010). Bandung: Focus Media.

Iqbal, M. (Ed.). (1986). Distributive Justice and the Need fulfillment in an Islamic Economy. Islamabad and London: International Institute of Islamic Economics, International Islamic University and the Islamic Foundation.

Khan, F. (1995). Essays in Islamic Economics. United Kingdom: The Islamic Foundation.

Moleong, LJ (2007). Qualitative Research Methodology. Bandung: Youth Rosdakarya.

Rahim, SBA (2015). A Conceptual Framework of Distributive Justice in Islamic Economics. Al-Albab, 4 (1), 19-38. https://doi.org/10.24260/alalbab.v4i1.275

Sari, EK (2006). Introduction to the Law of Zakat and Waqf. Jakarta: Grasindo.

ZAKAT AS AN INSTRUMENT IN FISCAL POLICY | priyono | Al-mashlahah: Journal of Islamic Law and Islamic Social Institution. (Tt). Taken October 8, 2019, from

https://jurnal.staialhidayahbogor.ac.id/index.php/am/article/view/145 